Indonesian Journal of Biotechnology, December, 2013

Vol. 18, No. 2, pp.83-91

\title{
Characterization of Streptomyces spp. Producing Indole-3-acetic acid as Biostimulant Agent
}

\author{
Charlie Ester de Fretes, Langkah Sembiring and Yekti Asih Purwestri
}

Faculty of Biology, Universitas Gadjah Mada

\begin{abstract}
Twenty six isolates of Streptomyces spp. obtained from Cyperus rotundus L. rhizosphere were tested for ability to produce indole-3-acetic acid (IAA) in yeast malt extract (YM) medium containing $2 \mathrm{mg} / \mathrm{mL}$ tryptophan. Screening of the isolates for ability to produce IAA was carried out by adding Salkowski reagent in bacteria culture and was measured quantitatively by spectrophotometer at $\lambda 530 \mathrm{~nm}$. Thin Layer Chromatography (TLC) method was used to determine IAA. To ensure the IAA production in Streptomyces isolates, gene involved in IAA biosynthesis was detected by amplifying Tryptophan Monooxigenase (iaaM) gene. The study of the effect of tryptophan on the production of IAA was measured at different concentrations of tryptophan $(0,1,2,3$, $4,5 \mathrm{mg} / \mathrm{mL}$ ) in the bacterial culture. The result showed that there were two Streptomyces spp. isolates which could produce IAA, namely the isolates of Streptomyces sp. MS1 $(125.48 \mu \mathrm{g} / \mathrm{mL})$ and Streptomyces sp. BR27 $(104.13 \mu \mathrm{g} / \mathrm{mL})$. The TLC result showed that the compound in both isolates was identified to be IAA. The amplification results showed that iaaM gene was detected in both isolates. This results indicated that the IAM pathway is predicted involved in the biosynthesis of IAA in the selected isolates. Both of the isolates were able to produce IAA after $24 \mathrm{~h}$ incubation and the highest production was at $120 \mathrm{~h}$ incubation with the concentration of tryptophan was $2 \mathrm{mg} / \mathrm{mL}$ dan $1 \mathrm{mg} / \mathrm{mL}$, respectively. Therefore, it is concluded that Streptomyces spp. isolates are able to produce IAA and potentially to be utilized as biostimulat agent.
\end{abstract}

Keywords: Streptomyces spp., indole-3-acetic acid (IAA), indole-3-acetamide (IAM), Tryptophan Monooxigenase gene (iaaM)

\section{Introduction}

Bacteriastrain that provideadvantageous to the plant growth is classified as Plant Growing Promoting Rhizobacteria (PGPR) (Kloepper, 1991). The PGPR could be used as biostimulant, which was able to produce or change the concentration of plant hormone, such as indole-3-acetic acid (IAA), gibberellic acid, cytokinin and ethylene (Fernando et al., 2005). Auxin is a compound containing indole ring on its structure which has the ability to increase the plant growth by stimulating the cell elongation, root initiation, and the seed growth (El-Tarabily, 2008). IAA is a

*Corresponding author:

Yekti Asih Purwestri

Biochemistry Laboratory, Faculty of Biology. Universitas Gadjah Mada, e-mail: yekti@ugm.ac.id/ yektiugm@yahoo.com natural auxin and a metabolism product of $L$-tryptophan in microorganism. As much as $80 \%$ of rhizosphere bacteria could secrete IAA (Bhavdish et al., 2003). Streptomycess in rhizosphere produce growth stimulating substances such as auxin, gibberellin (Brown, 1972; Aldesuquy et al., 1998) and cytokinin (Aldesuquy et al., 1998).

Research conducted by Tuomi et al. (1994) showed that Streptomyces griseoviridis produced IAA in vitro which might stimulate the plant growth. Several studies showed that several Streptomyces species such as $S$. olivaceoviridis, S. rimosus, S. rochei (Aldesuquy et al., 1998), S. lydicius WYEC108 (Tokala et al., 2002), and Streptomyces spp. (ElTarabily, 2008) had the ability to produce IAA and increased the growth of wheat and legume of Pisum satioum. Khanna et al. (2010) 
reported that Streptomyces sp. CMU-H009 isolated from rhizosphere Cymbopogon citrates produce IAA and stimulate the growth and the elongation of corn's root and beans. This indicated that Streptomyces had great potential to produce IAA which could be employed as biostimulant agent.

In bacteria, there are different pathways in synthesizing IAA and several bacteria strain might perform more than one synthetic pathway (Costacurta and Vanderleyden, 1995). The two main biosynthetic pathways of IAA were indole-3-acetamide (IAM) and indole-3-pyruvate (IpyA). The former has been identified on Bradyrhizobium japonicum dan Rhizobium fredii (Sekine et al., 1989), Azospirillum brasilense (Bar and Okon, 1993), Agrobacterium tumefaciens and Pseudomonas savastanoi (Comai and Kosuge, 1982; Yamada et al., 1985) and Streptomyces spp. (Manulis et al., 1994). In this pathway, there were two enzymes involved. They are tryptophan monooxigenase (IaaM) coded by iaaM gene and IAM hydrolase (IaaH) coded by iaaH (Spaepen et al., 2007). Therefore, functional gene involved in the biosynthesis of IAA could be found on the isolate of Streptomyces spp. which could produce IAA.

This research was aimed to evaluate the ability of Streptomyces spp. isolated from Cyperus rotundus L. rhizosphere in producing IAA, to ensure the production of IAA on the isolate through iaaM gene detection, as well as to determine the effect of tryptophan on the ability of isolate to produce IAA.

\section{Materials and Methods \\ Sub-culture of Streptomyces spp. isolate}

As much as 26 Streptomyces spp. isolates employed in this study was cultivated on the mediums of yeast malt extract (YM) broth and starch nitrate agar (SNA). From each isolate, $0.1 \mathrm{~mL}$ was taken from the glycerol stock and was inoculated in $5 \mathrm{~mL}$ of YM medium at $\mathrm{pH} 7$. The incubation was conducted for 3 days at room temperature. Then, $0.1 \mathrm{~mL}$ of culture was inoculated to the SNA medium using spread plate method and was incubated at room temperature. The observation was conducted from 4 days to 3 weeks, then it was streaked and stored on SNA medium as the stock.

\section{Screening of Streptomyces spp. which might produce indole-3-acetic acid (IAA)}

The ability of Streptomyces spp. isolates in producing IAA was conducted using method of Bano and Mussarat (2003). The isolate was suspended onto $0.5 \mathrm{~mL}$ of sterile aquadest and then was vortexed. As much as $0.1 \mathrm{~mL}$ of suspension was taken and was inoculated using spread plate method on the YM media and was incubated on the room temperature for 5 days. After the colony grew, the colony was taken using cylinder (diameter of $8 \mathrm{~mm}$ ) and was inoculated onto $5 \mathrm{~mL}$ of YM broth containing $2 \mathrm{mg} / \mathrm{mL}$ of L-tryptophan on $\mathrm{pH} 7$. The culture was incubated at $30^{\circ} \mathrm{C}$ and was shaken at 125 rpm for 7 days. The culture was centrifuged on $11,000 \mathrm{~g}$ for $15 \mathrm{~min}$. The supernatant (1 $\mathrm{mL}$ ) was mixed with $2 \mathrm{~mL}$ of Salkowski reagent and the mixture was left standing for $30 \mathrm{~min}$. The production of IAA was indicated by the presence of pink color. The quantitative analysis of IAA was conducted using spectrophotometer at $\lambda 530 \mathrm{~nm}$.

\section{Detection and identification of indole 3-acetic acid (IAA)}

Identification of IAA was conducted using thin layer chromatography (TLC). The isolate was inoculated onto $200 \mathrm{~mL}$ of YM broth media which had been added with tryptophan at pH 7 (Khamna et al., 2010). Tryptophan was added with the concentration of 1 and $2 \mathrm{mg} / \mathrm{mL}$ for the cultures of Streptomyces sp. MS1 and Streptomyces sp. BR27, respectively. The culture was incubated at $30^{\circ} \mathrm{C}$ and was shaken at $125 \mathrm{~g}$ for 5 days. The culture was centrifuged at 4,000 $\mathrm{g}$ for $15 \mathrm{~min}$. The supernatant $(150 \mathrm{~mL})$ was then extracted with $100 \mathrm{~mL}$ of ethyl acetate. The organic layer was placed on the flask and was evaporated to give the solid phase. The phase was dissolved with $2 \mathrm{~mL}$ of methanol. Then, 
$10 \mu \mathrm{l}$ of solution was spotted on the silica gel plate. As much as $0.5 \mathrm{mg}$ of synthetic IAA was dissolved in $2 \mathrm{~mL}$ of methanol. $10 \mu \mathrm{l}$ of solution was spotted on the same silica gel plate as the control. The TLC was performed with the eluent of chloroform:ethyl acetate: formic acid (5:4:1). The spot was visualized under UV transilluminator as blue spot at $254 \mathrm{~nm}$.

\section{Detection of iaaM gene on the Streptomyces spp. isolate}

Isolation of chromosomal DNA was conducted using spooling with a glass rod method (Irawati, 2006) with a slight modification. The Streptomyces spp. isolate was inoculated on the YM broth medium (50 $\mathrm{mL}$ ) at $\mathrm{pH} 7$ for 3-4 days. The culture was centrifuged at 3,000 $\mathrm{g}$ for $20 \mathrm{~min}$. The pellet was washed with $4 \mathrm{~mL}$ of $50 \mathrm{mM}$ EDTA solution and was centrifuged at 3,000 $\mathrm{g}$ for $15 \mathrm{~min}$. The obtained pellet was resuspended onto $2 \mathrm{~mL}$ of mixture (25\% sucrose: $0.5 \mathrm{M}$ EDTA: lysozyme $10 \mathrm{mg} / \mathrm{mL} 100 \mu \mathrm{L}$ ) and was incubated at $37^{\circ} \mathrm{C}$ for $1 \mathrm{~h}$. Then, 1200 $\mu \mathrm{L} \mathrm{NaCl} 5 \mathrm{M}, 700 \mu \mathrm{L}$ 0,5 M EDTA, $1500 \mu \mathrm{L}$ $20 \%$ SDS were added and the mixture was incubated at $56^{\circ} \mathrm{C}$ for $1 \mathrm{~h}$. Chloroform was then added and the mixture was slowly shaken for $20 \mathrm{~min}$ and was centrifuged at $3,000 \mathrm{~g}$. The supernatant was placed into the new conical flask and absolute ethanol was added ( $2 x$ volume). The DNA precipitation will appear. The centrifugation with slow speed was carried out to precipitate the DNA molecule. It was washed with ethanol $70 \%$ and was centrifuged. The pellet was dried and dissolved using TE buffer.

The amplification of iaaM was done using PCR thermal cycler method with the specific primer of iaaMF (5'CGACTTCTCCGACATGAACC'3) and iaaMR (5'AGTCGTCACAGGCGATCTTC'3). The condition of PCR was 1 cycle included the initial denaturation at $95^{\circ} \mathrm{C}$ for $3 \mathrm{~min}, 30$ cycles included the denaturation at $94^{\circ} \mathrm{C}$ for $30 \mathrm{~s}$, annealing at $55^{\circ} \mathrm{C}$ for $30 \mathrm{~s}$, extension at $72^{\circ} \mathrm{C}$ for $1 \mathrm{~min}$ and 1 last cycle included extension at $72{ }^{\circ} \mathrm{C}$ for $10 \mathrm{~min}$, cooling at $4{ }^{\circ} \mathrm{C}$ for $10 \mathrm{~min}$. The amplification product was visualized using electrophoresis for $20 \mathrm{~min}$ (100 volt). The bacteria isolate which show DNA band with the size of $500 \mathrm{bp}$ on the electrophoresis gel was considered has the functional gene.

\section{The effect of incubation time on the production of indole-3-acetic acid (IAA) by the selected isolates}

The selected Streptomyces isolate was suspended on the sterile aquadest and was mixed by vortexing. The suspension $(0.1$ $\mathrm{mL}$ ) was taken and inoculated using spread plate method in the agar YM media and was incubated at the room temperature for 5 days. Then, the colony (10 disc with diameter of $8 \mathrm{~mm}$ ) was taken and was cultivated in 50 $\mathrm{mL}$ of YM broth media containing $2 \mathrm{mg} /$ $\mathrm{mL} L$-tryptophan at $\mathrm{pH} 7$. The culture was incubated at $30^{\circ} \mathrm{C}$ and was shaked at 125 rpm for 7 days. The determination of IAA concentration was conducted each $24 \mathrm{~h}$. The culture was centrifuged at 11,000 $\mathrm{g}$ for 15 min, then the supernatant $(1 \mathrm{~mL})$ was mixed with $2 \mathrm{~mL}$ of Salkowski reagent and was left standing for $30 \mathrm{~min}$. The quantitative analysis was conducted by using spectrophotometer at $\lambda 530 \mathrm{~nm}$.

\section{The effect of tryptophan concentration on the production of indole-3-acetic acid (IAA) by the selected isolates}

The selected Streptomyces isolate was suspended on the sterile aquadest $(0.5 \mathrm{~mL})$ and was vortexed. The suspension $(0.1 \mathrm{~mL})$ was taken and was inoculated using spread plate method in the agar YM media and was incubated at the room temperature for 5 days. Then, the colony (10 disc with diameter of 8 $\mathrm{mm}$ ) was taken and was cultivated in $50 \mathrm{~mL}$ of YM broth media containing L-tryptophan at different concentration $(0,1,2,3,4,5$ $\mathrm{mg} / \mathrm{mL}$ ). The culture was incubated at 30 ${ }^{\circ} \mathrm{C}$ and was shaked at $125 \mathrm{rpm}$ for 5 days. The determination of IAA concentration was conducted each $24 \mathrm{~h}$. The culture was 
centrifuged at $11,000 \mathrm{~g}$ for $15 \mathrm{~min}$, then the supernatant $(1 \mathrm{~mL})$ was mixed with $2 \mathrm{~mL}$ of Salkowski reagent and was left standing for $30 \mathrm{~min}$. The quantitative analysis was conducted by using spectrophotometer at $\lambda 530 \mathrm{~nm}$. Next, the centrifugation product was filtered. The pellet was dried on the oven at $70^{\circ} \mathrm{C}$ and was weighed at each $6 \mathrm{~h}$ to determine the weight of dry cell.

\section{Results and Discussion}

Screening of Streptomyces spp. which might produce indole-3-acetic acid (IAA)

The ability of 26 isolates of Streptomyces spp. from rhizosfer Cyperus rotundus L. in producing indole-3-acetic acid (IAA) was evaluated. The evaluation showed that there were 2 isolates $(7.7 \%)$ which had the ability to convert amino acid of tryptophan to IAA, they were Streptomyces sp. MS1 and Streptomyces sp. BR27. Bhavdish et al. (2003) reported that the ability of rhizosfer bacteria to produce IAA was due to the high input of organic material from the root. The amount of IAA produced from the isolates could be seen on Table 1.

Table 1 . The ability of two Streptomyces isolates in producing IAA

\begin{tabular}{cc}
\hline Isolate & Concentration of IAA $(\mu \mathrm{g} / \mathrm{mL})$ \\
\hline MS1 & 79.52 \\
BR27 & 17.38 \\
\hline
\end{tabular}

Rhizosphere area was plant area affected by the root and was identified by the high microbial activity due to the abundance of exudates (Fitter and Hay, 2002). The released exudates by the root contained various amino acid (Walker et al., 2003), sugar, organic acid, phenolic compound and protein (Bais et al., 2006).

The results showed that the two isolates produced IAA in the different amount. Tsavkelova et al. (2005) stated that the bacteria with the same genus might produce IAA in the different amount. The amounts of IAA produced by actinomycetes (Gangwar et al., 2012) and Streptomyces sp. CMU-H009
(Khamna et al., 2010) were 17-39, $300 \mu \mathrm{gmL}^{-1}$, respectively.

Detection and identification of indole-3acetic acid (IAA) produced by Streptomyces MS1 and Streptomyces BR27 using thin layer chromatography (TLC)

IAA MS1 IAA BR27

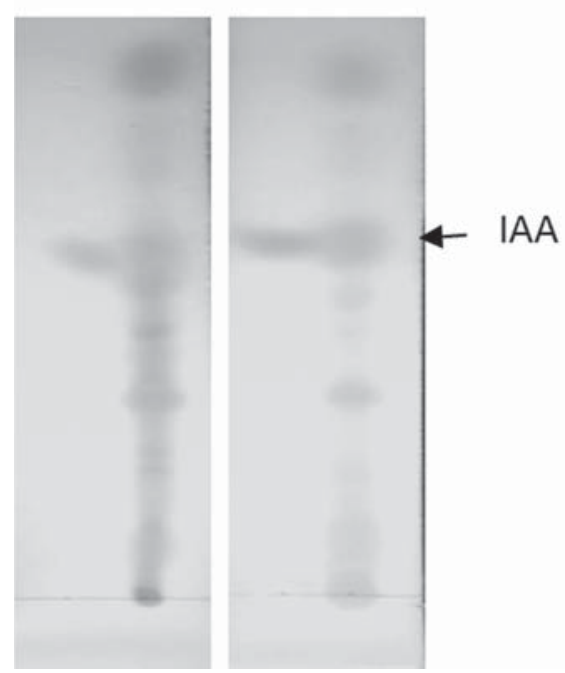

Figure 1. Thin Layer Chromatography profile of IAA produced by two isolates of Streptomyces sp. MS1 and Streptomyces sp. BR27 under UV $254 \mathrm{~nm}$. Syntetic IAA used as internal standard.

The thin layer chromatography (TLC) analyses at the wavelength of $254 \mathrm{~nm}$ (Figure 1) showed that IAA produced by two isolates of Streptomyces sp. MS1 and Streptomyces sp. BR27 provide spot with same Rf value of synthetic IAA (0.55). This indicated that both isolates might produce IAA.

Detection of tryptophan monoxigenase (iaaM) gene on Streptomyces sp. MS1 and Streptomyces sp. BR27

The iaaM was a gene involved in the biosynthesis of IAA on the IAM pathway. Meanwhile, iaaM was detected in both isolates isolate which were shown by the presence of single band on the size of $500 \mathrm{bp}$ (Figure 2). This result indicated that the production of IAA occurred via the IAM pathway. 


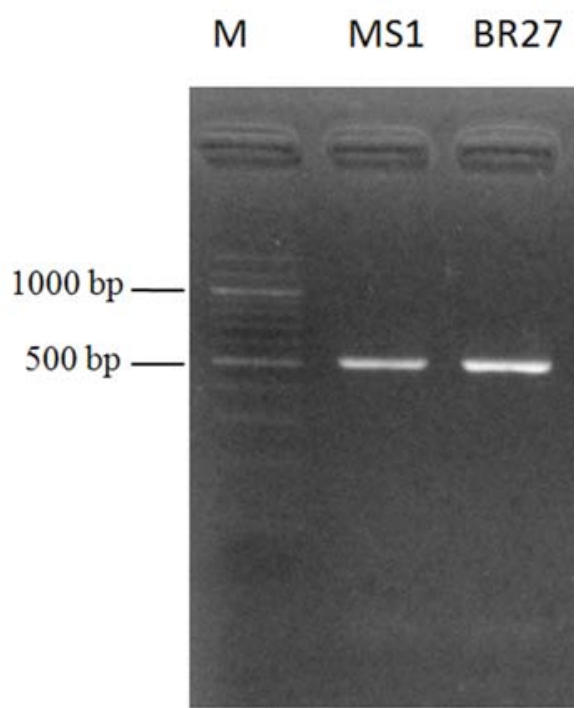

Figure 2. The iaaM involved in auxin biosynthesis pathway was detected in chromosomal DNA of both Streptomyces sp. MS1 and Streptomyces sp. BR27. M : DNA marker 100 bp ladder

Two biosynthetic pathways of IAA that commonly found in the bacteria wereIAM and IPyA pathways (Lambrecht et al., 2000). The production of IAA through the IAM pathway was controlled by different mechanism, including the input of tryptophan, the inhibition of the feedback of iaaM activity by IAA and IAM (Hutcheson and Kosuge, 1985). According to Hutcheson and Kosuge (1985), the biosynthesis of IAA through IAM pathway: Tryptophan $+\mathrm{O}_{2} \rightarrow \mathrm{IAM}+\mathrm{CO}_{2}+$ $\mathrm{H}_{2} \mathrm{O}$ and then IAM $+\mathrm{H}_{2} \mathrm{O} \rightarrow \mathrm{IAA}+\mathrm{NH}_{4}$.

Manulis et al. (1998) reported that the expression of iaaM was high when the bacteria was in apoplast while expression of
ipdC gene (key gene on the IPyA pathway) was high when the bacteria was found in the leave surface. Patten and Glick (1996) stated that if the microbial had several biosynthetic pathways to produce IAA, the pathway with the enzyme which was able to work at the environmental condition will dominantly occur in the biosynthesis of IAA. This indicated that the biosynthesis of IAA was adjusted for the expression on the different environment. Bacterias which employed IAM pathway in synthesizing IAA were Agrobacterium tumefaciens (Morris, 1995), Bradyrhizobium (Sekine et al., 1989), Pseudomonas syringae, Pantoea agglomerans, dan Rhizobium (Sekine et al., 1989; Theunis et al., 2004; Spaepen et al., 2007).

Effect of incubation time on the production of indole-3-acetic acid (IAA) by Streptomyces sp. MS1 and Streptomyces sp. BR27

The results showed that the production of IAA by Streptomyces sp. MS1 and Streptomyces sp. BR27 was commenced after $24 \mathrm{~h}$ and reach the maximum point at 120 $\mathrm{h}(5 \mathrm{~d})$ and decreased. The amount of IAA produced by two isolates from 0-168 h was presented in Figure 3. The results showed that the incubation time played significant role on the production of IAA by the two isolates. This effect gave different results for different strain of Streptomyces spp.. Streptomyces viridis CMU-H009 gave the maximum production of IAA after $72 \mathrm{~h}$

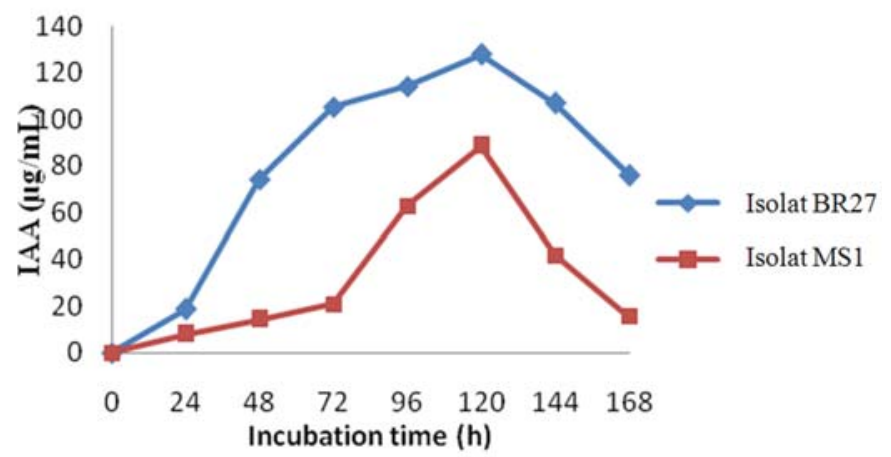

Figure 3. The effect of incubation time on the production of indole-3acetic acid (IAA) by Streptomyces sp. MS1 and Streptomyces sp. BR27. 


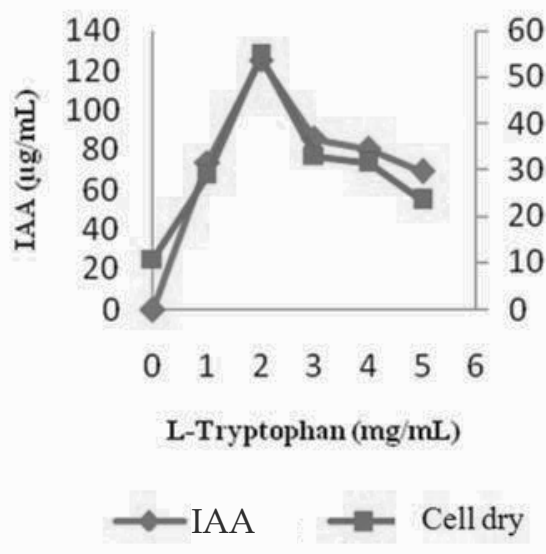

(a)

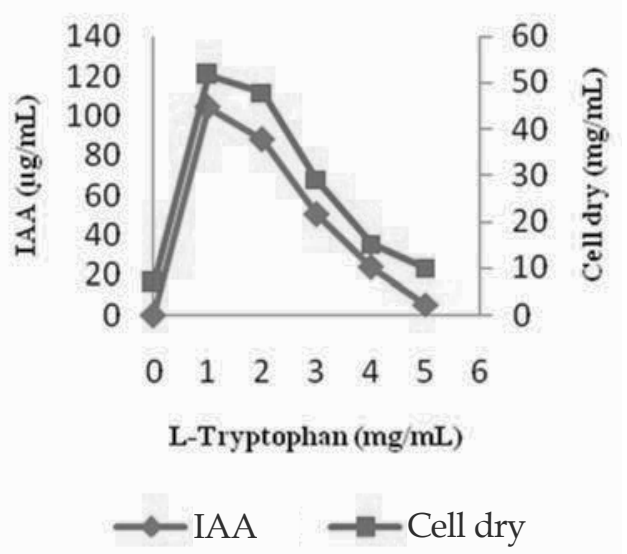

(b)

Figure 4. The effect of tryptophan concentration on the production of IAA and the cell dry weight on Streptomyces MS1 (a) and Streptomyces BR27 (b)

(3d) on the medium of YM broth containing $2 \mathrm{mg} / \mathrm{mL}$ of trypthophan (Khamna et al., 2010).

Walkinson et al. (1994) reported production of IAA from the bacteria isolate was affected by the incubation time. The decrease on the production of IAA might be due to the release of enzyme which might degrade IAA such as oxidase IAA and peroxidase produced by exudates as reported on Rhizobum sp. From Cajanus cajan (Datta and basu, 2000). Degradation of IAA could occur through the oxidation mechanim to produce dioxindole-3-acetic acid. The product was then oxidized into isatine which could be hydrolyzed into anthranilic acid in the acid condition (Jensen et al., 1995).

The effect of tryptophan concentration on the production of IAA and the cell dry weight on Streptomyces MS1 and Streptomyces BR27

The results showed that the production of IAA by the two isolates was linearly correlated to the cell dry weight. The production of IAA was increased by the increasing of the dry weight. The Streptomyces sp. MS1 (Figure 4a) and Streptomyces sp. BR27 (Figure $4 \mathrm{~b}$ ) might produce IAA with the tryptophan concentrations of 2 and $1 \mathrm{mg} / \mathrm{L}$, respectively. On the higher concentration, tryptophan provides bad effect on the production of IAA and the dry weight.
The concentration of tryptophan strongly affected by the ability of isolate in producing IAA. The IAA could not be produced without the addition of tryptophan on the medium. Tryptophan had been identified as the main precursor for IAA and played important role in modulating biosynthetic level of IAA on bacteria (Spaepen et al., 2007). Besides, tryptophan could be employed as the source of carbon and energy which will be decomposed into several compounds which in turn will be involved in the metabolism pathway (Moat and Foster, 1995).

Khamna et al. (2010) showed that the highest IAA production by Streptomyces viridis CHU-H009 on the medium YM broth with the tryptophan concentration of $2 \mathrm{mg} /$ $\mathrm{mL}$. However, the utilization of tryptophan on higher concentration resulted in bad effect on the production of IAA and the dry weight. Ahmad et al. (2005) reported that rhizosphere bacteria of Azotobacter spp. and Pseudomonas spp. produced the highest IAA on the medium of nutrient broth with the tryptophan concentration of 2 and 5 $\mathrm{mg} / \mathrm{mL}$. Bar and Okon (1993) showed that concentration of tryptophan of $1.4 \mathrm{mg} /$ $\mathrm{mL}$ or higher could inhibit the growth of Azospirillum brasilense Sp7.

The application of the exogenous tryptophan was required to increase the production of IAA in various bacteria, such 
as Azospirillum, Pseudomonas putida dan Rhizobium (Prinsen et al., 1993; Brandi and Lindow, 1996; Patten and Glick, 2002; Theunis et al., 2004). Tryptophan on rhizosphere could be obtained from the degradation of root cell and microbial cell and root exudates. This showed that IAA was produced during the late exponential and stationer phases (Omay et al., 1993).

Spaepen et al. (2007) mentioned that the role of IAA to the bacteria has not clearly known yet. However, IAA produced by the bacteria isolate might stimulate the growth of plant. The growth could initiate the exudation of root organic compounds which could be employed for bacteria growth.

\section{Conclusion}

This study showed that Streptomyces sp. MS1 and Streptomyces sp. BR27 produce IAA on the medium with the addition of tryptophan. In addition, the TLC analysis and amplification of iaaM gen showed that the two isolates produce IAA. Therefore, it is concluded that Streptomyces spp. isolates has potential as biostimulant agent.

\section{Acknowledgement}

This research was partly supported by Public Service Education Fund Management Institution (LPDP) master scholarship program 2012.

\section{References}

Ahmad, F., Ahmad, I. and Kha, M.S., 2005. Indole Acetic Acid Production by The Indigenous Isolates of Azotobacter and Fluorescent Pseudomonas in The Presence and Absence of Tryptophan. Turkish J of Biol., 29, 29-34.

Aldesuquy, H.S., Mansour, F.A. and AboHamed, S.A., 1998. Effect of The Culture Filtrates of Streptomyces on Growth and Productivity of Wheat Plants. Folia Microbiologica, 43, 465-470.

Bais, H.P., Weir, T.E., Perry, L.G., Gilroy, S. and Vovanco, J.M., 2006. The Role of Exudates in Rhizosfer Interactions with
Plants and Other Organism. The Annual Rev of Plant Biol., 57, 233-266.

Bano, N. and Musarrat, J., 2003. Characterization of a new Pseudomonas aeruginosa strain NJ-15 as a potential biocontrol agent. Curr. Microbiol., 46, 324-328.

Bar, T. and Okon, Y., 1993. Tryptophan conversion to indole-3-acetic acid via indole-3-acetamide in Azospirillum brasilense Sp7. Canadian J. of Microbiol., 39, 81-86.

Bhavdish, N., Johri, A., Sharma, J. and Virdi, S., 2003. Rhizobacterial diversity in India and its influence on soil and plant health. Adv in Biochem Eng/Biotechnol., 84, 49-89.

Brandl, M.T. and Lindow, S.E., 1996. Cloning And Characterization Of A Locus Encoding An Indolepyruvate Decarboxylase Involved In Indole-3Acetic Acid Synthesis In Erwinia herbicola. Appl. and Environ. Microbiol., 62, 41214128.

Brown, M.E., 1972. Plant Growth Substances Produced by Microorganism of Soil and Rhizosphere. J. of Appl. Bacteriol., 35, 443451.

Comai, L. and Kosuge, T., 1982. Cloning characterization of iaaM, a virulence determinant of Pseudomonas savastanoi. J. of Bacteriol., 149, 40-46.

Costacurta, A. and Vanderleyden, J., 1995. Synthesis of phytohormones by plantassociated bacteria. Critical Rev. in Microbiol., 21, 1-18.

Datta, C. and Basu, P.S., 2000. Indole Acetic Acid Production By a Rhizobium Species From Root Nodules Of A Leguminous Shrub, Cajanus cajan. Microbiol. Res., 155, 123-127.

El-Tarabily, K. A., 2008. Promotion of Tomato (Lycopersicon esculentum Mill.) Plant Growth by Rhizosphere Competent 1-aminocyclopropane-1-carboxylic Acid Deaminase-Producing Streptomycete Actinomycetes. Plant and Soil, 308, 161-174.

Fernando, D., Nakkeeran and Zhang, Y. (2005) Biosynthesis Of Antibiotics By 
PGPR And Its Relation In Biocontrol Of Plant Diseases. In: PGPR: Biocontrol and Biofertilization (Z.A. Siddiqui, ed.). pp 67-109. Springer, Dordrecht, The Netherlands.

Fitter, A.H. and Hay, R.K.M. (2002) Environmental Physiology of Plants. Academic Press. San Diego.

Hutcheson, S.W. and Kosuge, T., 1985. Regulation of 3-indole acetic acid production in Pseudomonas syringae pv. Savastanoi. J. of Biol. Chem., 260(10), 62816287.

Ilic, S.B., Konstantinovic, S.S., Todorovic, Z.B., Lazio, M.L., Veljkovic, V.B., Jokovio, N. and Radovanovic, B.C., 2007. Characterization and Antimicrobial Activity of The Bioactive Metabolites in Streptomyces Isolates., Microbiology, 76, 421-428.

Irawati, W. 2006. Kajian Fisiologis dan Molekular Sifat Resistensi Bakteri Terhadap Tembaga. Disertasi. Fakultas Biologi, Universitas Gadjah Mada. Yogyakarta.

Jensen, J.B., Egsgaard, H., Vanonckelen, H. and Jochimsen, B.U., 1995. Catabolism Of Indole-3-Acetic-Acid And 4-Chloroindole3-Acetic And 5-Chloroindole-3-Acetic Acid In Bradyrhizobium japonicum. J. of Bacteriol., 177, 5762-5766.

Khamna, S., Yokota, A., Peberdy, J. F. and Lumyong, S., 2010. Indole-3-acetic Acid Production by Streptomyces sp. Isolated From Thai Medicinal Plant Rhizosphere Soils. EurAsian J. of BioSci., 4, 23-32.

Kloepper, J. W. 1991. Plant GrowthPromoting Rhizobacteria as biological control agents of soilborne diseases. Di dalam: Petersen JB, editor. The Biological Control of Plant Diseases. Proceedings of The International Seminar 'Biological Control of Plant Diseases and Virus Vectors; Tsukuba, 17-21 September 1990. Japan: NARC. 142-148.

Lambrecht, M., Okon, Y., Vande Broek, A. and Vanderleyden, J., 2000. Indole-3Acetic Acid: A Reciprocal Signalling Molecule In Bacteria-Plant Interactions.
Trends in Microbiol., 8, 298-300.

Manulis, S., Shafrir, H., Epstein, E., Lichter, A. and Barash, I., 1994. Biosynthesis of indole-3-acetic acid via the indole-3acetamide pathway in Streptomyces spp. Microbiology., 140, 1045-1050.

Manulis, S., Haviv-Chesner, A., Brandl, M.T., Lindow, S.E. and Barash, I., 1998. Differential Involvement Of Indole-3Acetic Acid Biosynthetic Pathways In Pathogenicity And Epiphytic Fitness Of Erwinia herbicola pv. gypsophilae. Mol. Plant-Microbe Interactions, 11, 634-642.

Maziyah, S. 2011. Keanekaragaman dan potensi Streptomyces Rizosfer Rumput Teki (Cyperus rotundus L.) Daerah Tercemar Merkuri sebagai Agen Bioremediasi Cemaran Logam. Tesis. Fakultas Biologi UGM. Yogyakarta.

Moat, A.G. and Foster, J.W. (1995) Microbial Phsyology, Third Ed. John Wiley and Sons. New York.

Morris, R.O.,1995.GenesSpecifying Auxin And Cytokinin Biosynthesis In Prokaryotes. In: "Plant Hormones: Physiology, Biochemistry, and Molecular Biology" (Davies, P.J., ed.). pp 318-339. Dordrecht: Kluwer Academic Publishers.

Omay, S.H., Schmidt, W.A., and Martin, P., 1993. Indoleacetic Acid Production By The Rhizosphere Bacterium Azospirillum brasilense Cd Under In Vitro Conditions. Canadian J. of Microbiol., 39, 187-192.

Patten, C.L. and Glick, B.R., 2002. Regulation Of Indoleacetic Acid Production In Pseudomonas putida GR12-2 By Tryptophan And The Stationary-Phase Sigma Factor RpoS. Canadian J. of Microbiol., 48, 635642.

Prinsen, E., Costacurta, A,, Michiels, K., Vanderleyden, J., and Van Onckelen, H., 1993. Azospirillum brasilense Indole-3-Acetic Acid Biosynthesis: Evidence for a NonTryptophan Dependent Pathway. Mol. Plant-Microbe Interactions., 6, 609-615.

Sekine, M., Watabane, K., and Syono, K., 1989. Molecular Cloning of A Gene For Indole-3-acetamide Hydrolase From 
Bradyrhizobium japonicum. J. of Bacteriol., 171, 1718-1724.

Spaepen, S., Vanderleyden, J., and Remans, R., 2007. Indole-3-acetic Acid in Microbial and Microorganism-Plant Signaling. FEMS Microbiol. Rev., 10, 1-24.

Theunis, M., Kobayashi, H., Broughton, W. J., and Prinsen, E., 2004. Flavonoids, NodD1, NodD2, and Nod-box NB15 Modulate Expression Of The y4wEFG Locus That is Required for Indole-3-acetic Acid Synthesis in Rhizobium sp. Strain NGR234. Mol. Plant-Microbe Interactions., 17, 1153-1161.

Tokala, R. K., Strap, J.L., Jung, C.M., Crawford, D.L., Salove, M.H., Deobald, L.A., Bailey, J.F., and Morra, M.J., 2002. Novel Plant-Microbe Rhizosphere Interaction Involving Streptomyces lydicus WYEC108 and the Pea Plant (Pisum sativum). Appl. and Environ. Microbiol., 68, 2161-2171.

Tuomi, T., Laakso, S., and Rosenquist, H., 1994. Indole-3-acetic Acid Production by a Biofungicide Streptomyces griseoviridis A Strain. Annales Botanici Fennici, 31, 59-63.

Walker, T.S., Bais, H.P., Grotewold, E., and Vivanco, J.M., 2003. Root Exudation and Rhizosphere Biology. Plant Physiol., 132, 44-51.

Wilkinson, K.G., Sivasithamparam, K., Dixon, K.W., Fahy, P.C., and Bradley, J.K., 1994. Identification and Characterization of Bacteria Associated With Western Australian Orchids. Soil Biol. and Biochem., 26, 137-142.

Yamada, T., Palm, C., Brooks, B., and Kosuge, T., 1985. Nucleotide sequences of the Pseudomonas savastanoi indoleacetic acid genes show homology with Agrobacterium tumefaciens T-DNA. Proceedings of the National Academy of Sciences, 82, 65226526. 